\title{
DEGRADASI LIMBAH KHROM DAN DAUR ULANG UNTUK BAHAN PROSES PENYAMAKAN KULIT DENGAN MENGGUNAKAN KOAGULAN KAPUR TOHOR
}

\author{
Sri Yuniyarti ${ }^{1}$, Toni Isbandi ${ }^{2}$ \\ ${ }^{1}$ Teknik Lingkungan Institut Teknologi Yogyakarta \\ ${ }^{2}$ Teknik Industri Institut Teknologi Yogyakarta
}

\begin{abstract}
INTISARI
Industri penyamakan kulit adalah industri yang mengolah kulit mentah (hides atau skin) menjadi kulit tersamak (leather) dengan bahan penyamak. Prosesnya adalah dengan memasukkan bahan penyamak tertentu ke dalam jaringan serat kulit sehingga terjadi ikatan kimia antara bahan penyamak dengan serat kulit. Hasil dari proses penyamakan kulit tersebut diperoleh hasil samping yang berupa krom $\left(\mathrm{Cr}^{6+}\right.$ yang bersifat karsinogenik).Kandungan khromium sebagai kromium total $(\mathrm{Cr})$ dalam air bekas penyamakan krom berkisar 500-1500 mg/l. Konsentrasi kromium air buangan campuran dari proses penyamakan kulit akan menjadi sekitar 100-300 mg/l.Untuk menanggulangi dampak negatif yang ditimbulkan oleh limbah cair proses penyamakan kulit yang mengandung krom perlu dilakukan penanganan secara tepat, efektif dan efisien dengan teknologi ramah lingkungan dengan cara mendaur ulang sehingga limbah krom tersebut bisa dipakai kembali. Metode perlakuan $\mathrm{Ph}$, prosentase penambahan kapur tohor, kecepatan pengadukan (rpm) dan waktu pengadukan menjadi variable yang sangat menentukan dalam mendaur ulang limbah krom tersebut sehingga didapat prosentase pemisahan kromium yang dapat terjadi pada keadaan optimal adalah sebesar $99,9850 \%$

Kata kunci : kulit, krom, limbah krom
\end{abstract}

\section{DEGARADTION CHROMIUM WASTE AND RECYCLING FOR CHEMICAL PROCESS USING COAGULANT TANNERY QUICKLIME}

\begin{abstract}
The tannery industry is an industry that processes raw skin (hides or skins) into leather with tanning material. The process is to insert a particular tanner into the fibrous tissue of the skin resulting in a chemical bond between the tanner and the skin fibers. The results of the leather tanning process resulted in chromium (Cr6 + carcinogenic) side-effects. . The chromium content as total chromium $(\mathrm{Cr})$ in chrome tanning water ranges from 500-1500 $\mathrm{mg} / \mathrm{l}$. The concentration of chromium wastewater mixture from the tanning process will be about 100-300 $\mathrm{mg} / \mathrm{l}$. To overcome the negative impact of liquid waste from the process of tannery containing chromium, it is necessary to handle precisely, effectively and efficiently with environmentally friendly technology by recycling so that chrome waste can be reused. Phase treatment method, the percentage of lime addition, stirring rate (rpm) and stirring time become a very decisive variable in recycling chrome waste so that the percentage of chromium separation that can occur in optimal condition is $99,9850 \%$. Keyword : leather, chrome, chrome waste
\end{abstract}




\section{A. PENDAHULUAN}

Industri penyamakan kulit adalah industri yang mengolah kulit mentah (hides atau skin) menjadi kulit tersamak (leather) dengan bahan penyamak. Prosesnya adalah dengan memasukkan bahan penyamak tertentu ke dalam jaringan serat kulit sehingga terjadi ikatan kimia antara bahan penyamak dengan serat kulit. Hal tersebut akan mengakibatkan sifat fisik kulit berubah menjadi lebih baik dibandingkan dengan kulit mentahnya. Sifat tersebut antara lain kelemasannya, ketahanannya terhadap panas dan dingin serta ketahanannya terhadap gesekan (Sharphouse, 2009; Thornstensen, 2007). Bahkan penelitian mengenai penyamakan kulit saat ini sudah sampai pada level nanoteknologi (Pan, Li, Liu, Wang, \& Wang, 2017)

Dalam proses penyamakan kulit, digunakan bahan penyamak krom. Hasil dari proses penyamakan kulit tersebut diperoleh hasil samping yang berupa krom $\left(\mathrm{Cr}^{6+}\right.$ yang bersifat karsinogenik).Limbah cair dari proses penyamakan kulit sangat kompleks, sifatnya ditandai dengan kandungan BOD, padatan tersuspensi dan padatan total yang tinggi, yang terdiri dari bahan-bahan organik terlarut dan anaorganik, berwarna dan berbau (Iswahyuni, 2009 hal 2). Di Amerika untuk mengurangi bahaya krom pada lingkungan dengan cara mengurangi kadar krom pada proses penyamakan (Pan et al., 2017).

Berdasarkan pemantauan limbah penyamakan kulit yang dihasilkan penyamakan kulit terus bertambah jumlahnya sejalan dengan peningkatan kapasitas produksi industri penyamakan kulit yang ada di Indonesia. Kandungan khromium sebagai kromium total $(\mathrm{Cr})$ dalam air bekas penyamakan krom berkisar 500-1500 mg/l. Konsentrasi kromium air buangan campuran dari proses penyamakan kulit akan menjadi sekitar 100-300 mg/l. Keadaan ini menjadi masalah dalam pengolahan air limbah penyamakan kulit dan menjadi beban masalah lingkungan, apalagi dibuang begitu saja. Hal ini disebabkan karena pengolahan air limbah penyamakan kulit oleh industri saat ini sangat berkurang.(LP3S,2010). Untuk menekan dampak cemaran pada penyamakan, saat ini digunkan krom AS. Krom AS adalah proses penyamakan yang efektif dan ramah lingkungan yang dapat menghasilkan produk kulit berkualitas lebih baik dalam waktu proses yang lebih singkat dengan dosis kromium yang lebih rendah(Pan et al., 2017).

Penanggulangan dampak negatif yang ditimbulkan oleh limbah cair dari proses penyamakan kulit yang mengandung krom, perlu dilakukan penanganan secara tepat, efektif dan efisien. Pemanfaatan limbah Khrom dengan cara daur ulang untuk dijadikan sebagai bahan 
proses penyamakan kulit merupakan teknologi yang ramah lingkungan.

\section{B. TINJAUAN PUSTAKA}

\section{Proses Penyamakan Kulit}

Proses penyamakan kulit adalah suatu proses yang mengubah kulit mentah (hides/skins) menjadi kulit jadi atau kulit tersamak (leather) yang siap untuk dibuat sebagai bahan jadi. Dari proses tersebut terdapat perbedaan yang nyata baik sifat kimia maupun sifat fisika. Kulit mentah mudah sekali menjadi busuk, dalam keadaan kering kulit keras dan kaku. Sedang kulit tersamak adalah yang mempunyai sifat lentur, tahan lama dan merupakan bahan baku siap pakai. (Sharaphouse, 2008; Thornstensen, 2010).

(Lofrano, Meriç, Zengin, \& Orhon, 2013), menyatakan bahwa kulit terbentuk dari reaksi serat kalogen dalam kulit hewan dengan tannin, khrom, tawas atau zat penyamak lainnya. Untuk mengubah kulit hewan digunakan dua proses, yaitu : proses rumah balok dan proses rumah semak. Dalam proses rumah balok, kulit hewan dibersihkan dan disiapkan untuk penyamakan. Pertama kulit direndam dalam air untuk menghilangkan kotoran darah dan kotoran yang menempel pada kulit, kemudian kulit dibersihkan dengan mesin atau tangan untuk menghilangkan sisasisa daging yang ada. Penghilangan bulu dilakukan secara kimia, dengan tangan dan/atau mesin. Bubuk kapur tohor digunakan untuk melepaskan bulu kemudian jika bulu itu akan digunakan dapat dilarutkan dengan natrium sulfida dan/atau natrium sulfihidrat.

Langkah pertama dalam proses penyamakan kulit adalah perendaman amonia, yaitu kulit hewan direndam dalam larutan garam amonia dan enzim. Semua kulit hewan untuk penyamakan khrom harus mengalami proses pengasaman terlebih dahulu. Proses pengasaman membuat kulit hewan bersifat asam menggunakan asam sulfat dan natrium klorida. Penyamakan itu sendiri dilakukan dalam tong yang berisi tannin nabati (kulit pohon, kayu dan buah atau akar), atau campuran kimia yang mengandung khrom sulfat. Pemucatan, pemberian warna, cairan lemak digunakan untuk kulit khusus yang akan diberi warna. Langkahlangkah akhir seperti pengeringan, perentangan dan penekanan kulit adalah menggunakan proses kering.

\section{Sumber dan karakteristik limbah cair \\ Dilihat dari asal beban} pencemar, maka sumber dan sifat air limbah industri penyamakan kulit dapat dibedakan pertahapan proses menurut (ESCAP, 2008), adalah sebagai berikut:

a. Perendaman (Soaking).

Air limbah soaking mengandung sisa daging, darah, 
bulu, garam, mineral, debu dan kotoran lain, atau bahkan bakteri anthrax. Selanjutnya dikatakan bahwa air berbau busuk, kotor, dengan kandungan suspended solid 0,05-0,1 \%. Volume limbah soaking berkisar antara 2,5-4 1/kg kulit, $\mathrm{pH} \mathrm{7,5-8,} \mathrm{total}$ solid $\quad 8.000-28.000 \quad \mathrm{mg} / \mathrm{l}$, suspended solid $2.500-4.000$ $\mathrm{mg} / \mathrm{l}$.

b. Buangan bulu dan pengapuran (Unhairing dan liming)

Air limbah pengapuran berwarna putih kehijauan dan kotor, berbau menyengat, $\mathrm{pH}$ 910, mengandung kalsium, natrium sulfat, albumin, bulu, sisa daging dan lemak, suspended solid 3,6 \% (Kzoziorowski dan Kucharski, 2007). Air limbah unhairing dan liming mengandung total solid $16.000-45.000 \mathrm{mg} / \mathrm{l}$, suspended solid 4.500-6.500 mg/l, BOD 1.100-2.500 mg/l, pH 10-12,5.

c. Air limbah buangan kapur (deliming)

Air limbah dari proses deliming mempunyai bahan polutan yang lebih kecil dibanding dengan unhairing dan limning. Air limbah ini mempunyai volume $700-800$ 1/ton kulit mentah, $\mathrm{pH} 3-9$, total solid 1.200-12.000 $\mathrm{mg} / \mathrm{l}$, suspended solid 200-1.200 mg/l dan BOD 1.000-2.000 mg/l.

d. Air limbah pengikisan protein (Degreasing)
Akan menyebabkan pencemaran air yang akan ditunjukan dengan tingginya nilai COD, BOD, DS dan lemak.

e. Air limbah pikel (Pickling) dan khrom (Tanning)

Air limbah dari proses ini akan mengandung bahan protein, sisa garam, sejumlah kecil mineral, dan krom valensi 3 yang apabila tercampur dengan alkali akan terbentuk krom

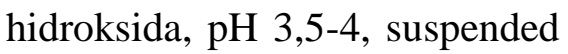
solid $0,01-0,02 \%$.

f. Air limbah gabungan termasuk pencucian

Air limbah ini mempunyai volume $30-351 / \mathrm{kg}, \mathrm{pH}$ 7,5-10, total solid 10.000-25.000 mg/l, suspended solid 1.250-6.000 $\mathrm{mg} / \mathrm{l}$ dan BOD 2.000-3.000 $\mathrm{mg} / \mathrm{l}$.

\section{Kromium}

Berdasarkan pada sifat-sifat kimianya logam $\mathrm{Cr}$ dalam persenyawaan mempunyai bilangan oksidasi $2+, 3+$, dan 6+. Logam ini tidak dapat teroksidasi oleh udara yang lembab, dan bahkan pada proses pemanasan cairan logam $\mathrm{Cr}$ teroksidasi dalam jumlah yang sangat sedikit sekali. Akan tetapi dalam udara yang mengandung $\mathrm{CO}_{2}$ (karbondioksida) dalam konsentrasi tinggi, logam $\mathrm{Cr}$ dapat mengalami peristiwa oksidasi dalam bentuk $\mathrm{Cr}_{2} \mathrm{O}_{3}$. Sedangkan dalam larutan $\mathrm{HCl}$ (asam klorida) akan membentuk logam $\mathrm{CrCl}_{2}$ (cromium diklorida). 
Kromium merupakan logam yang sangat mudah bereaksi. Logam ini secara langsung dapat bereaksi dengan nitrogen, karbon, silica, dan boron.

Sesuai dengan tingkat valensi yang dimiliki, logam atau ion-ion khromium yang telah membentuk senyawa, mempunyai sifat-sifat yang berbeda-beda sesuai dengan tingkat ionitasnya. Senyawa yang terbentuk dari ion logam $\mathrm{Cr}^{2+}$ akan bersifat basa, senyawa yang terbentuk dari ion logam $\mathrm{Cr}^{3+}$ bersifat amfoter, dan senyawa yang terbentuk dari ion logam $\mathrm{Cr}^{6+}$ akan bersifat asam (Haryando Palar, 2011 hal 135).

$\mathrm{Cr}^{3+}$ dapat mengendap dalam bentuk hidroksida. Pada kromium hidroksida ini tidak larut, kondisi optimal $\mathrm{Cr}^{3+}$ dicapai dalam air $\mathrm{pH}$ antara 8,5-9,5. Kromium hidroksida ini melarut akan lebih tinggi apabila kondisi $\mathrm{pH}$ rendah atau asam. $\mathrm{Cr}^{6+}$ sulit mengendap, sehingga dalam penangannannya memerlukan zat pereduksi untuk mereduksi menjadi $\mathrm{Cr}^{3+}$ (Haryando palar 2009).

Kromium umumnya dapat berbentuk padatan (kristal $\mathrm{Cr}_{2} \mathrm{O}_{3}$ ) . Kromium larutan biasanya basa dengan $\mathrm{pH}$ 8-10 terjadi pengendapan $\mathrm{Cr}$ dalam bentuk $\mathrm{Cr}(\mathrm{OH})_{3}$. Sebenarnya kromium dalam bentuk ion trivalen tidak begitu berbahaya dibandingkan dengan bentuk hexavalen, akan tetapi apabila bertemu dengan oksidator dan kondisinya memungkinkan $\mathrm{Cr}^{3+}$ tersebut akan berubah menjadi $\mathrm{Cr}^{6+}$ (Haryando palar, 1994).

Khromium telah dimanfaatkan secara luas dalam kehidupan manusia. Logam ini banyak digunakan sebagai bahan pelapis (plating) pada bermacam-macam peralatan, mulai dari peralatan rumah tangga sampai ke mobil. Cr juga banyak dibentuk untuk menjadi alloy. Bentuk alloy dari $\mathrm{Cr}$ sangat banyak dan juga mempunyai fungsi pemakaian yang sangat luas dalam kehidupan.

Persenyawaan lain yang dapat dibentuk dengan menggunakan logam $\mathrm{Cr}$ seperti senyawa-senyawa kromat dan dikhromat sangat banyak digunakan oleh perindustrian. Kegunaan yang umum dikenal dari senyawa-senyawa krhomat dan dikhromat ini adalah dalam bidangbidang seperti litigrafi, tektil, penyamakan, pencelupan, fotografi, zat warna, sebagai bahan peledak dan sebagai geretan (korek api) serta masih banyak lagi kegunaan lainnya (Haryando palar, 1994 hal 136).

\section{Pendaurulangan limbah cair khrom}

Untuk mengurangi kromium yang terbuang dan tertinggal dalam limbah cair proses penyamakan kulit dapat dilakukan dengan metode berikut ini :

a. Direct krom reusingadalah daur ulang sisa cairan krom yang langsung digunakan pada proses penyamakan dan berikutnya 
dengan menambah bahan krom segar.

b. Indirect krom reusingadalah pertama mengambil sisa krom dalam cairan bekas penyamakan krom dengan menambahkan bahan pengendap krom, pemisahan dan pelarutan endapan krom dengan asam.

Reaksi antara ion khrom dan padatan kapur tohor mengikuti persamaan:

$2 \mathrm{Cr}^{3+}+3 \mathrm{Ca}(\mathrm{OH})_{2} \rightarrow 2 \mathrm{Cr}(\mathrm{OH})_{3} \downarrow$ $+3 \mathrm{Ca}^{2+}$

Hasil kali kelarutan $\mathrm{Ca}(\mathrm{OH})_{2}$ pada suhu lingkungan sebesar $6,5 \mathrm{x}$ $10^{-6}$ (Brady, 1990), sedangkan hasil kali kelarutan $\mathrm{Cr}(\mathrm{OH})_{3}$ sebesar 2,9 $\mathrm{x} 10^{-29}$ (Vogel, 1953). Setiap molekul $\mathrm{Ca}(\mathrm{OH})_{2}$ yang bereaksi akan digantikan oleh molekul $\mathrm{Cr}(\mathrm{OH})_{3}$ yang terbentuk, karena hasil kali kelarutan $\mathrm{Cr}(\mathrm{OH})_{3}$ jauh lebih kecil dibandingkan dengan hasil kali kelarutan $\mathrm{Ca}(\mathrm{OH})_{2}$, hasil padat $\mathrm{Cr}(\mathrm{OH})_{3}$ yang terbentuk akan menempel diluar $\mathrm{Ca}(\mathrm{OH})_{2}$ yang belum bereaksi. Sehingga setiap kali $\mathrm{Cr}(\mathrm{OH})_{3}$ terbentuk maka akan langsung mengendap.

$$
\text { Pada pelarutan endapan }
$$

kromium hidroksida $\left\{\mathrm{Cr}(\mathrm{OH})_{3}\right\}$ dengan $\mathrm{H}_{2} \mathrm{SO}_{4}$ akan terjadi reaksi sebagai berikut:

$2 \mathrm{Cr}(\mathrm{OH})_{3} \downarrow$

$2 \mathrm{H}_{2} \mathrm{SO}_{4} \rightarrow 2 \mathrm{Cr}\left(\mathrm{SO}_{4}\right)(\mathrm{OH})_{3}+2 \mathrm{H}_{2} \mathrm{O}$

\section{METODE PENELITIAN}

\section{Variabel Penelitian}

a. Variabel Terikat, yaitu kandungan Khrom.

b. Variabel Bebas, yaitu :

- Variasi dosis Kapur Tohor $(2,0 ; 4,0 ; 6,0 ; 8,0$; 10 ; 12) $\mathrm{ml}$.

- Waktu Kontak, yaitu $(10 ; 30 ; 45 ; 120)$ menit.

\section{Alat dan Bahan Penelitian}

a. Alat yang digunakan dalam penelitian ini antara lain :

1) Alat proses daur ulang dari Fiber glass berdiameter $50 \mathrm{~cm} \quad \&$ tinggi $80 \mathrm{~cm}$.

2) Pipa pralon dengan diameter $1 / 4$ inci.

3) 4 buah stoper dengan diameter $=1 / 4$ inci.

4) 5 buah Jerigen@30 liter.

5) lembar kain kasa.

6) Beaker glass, 1 buah $1000 \mathrm{ml}$.

7) Penghitung waktu (stopwatch).

8) Botol sampel $500 \mathrm{ml}$

9) Botol gelap steril volume 1 liter

10) Pipet ukur dan Kapas

\section{b. Bahan}

Bahan-bahan yang digunakan dalam penelitian ini ; 
1) Larutan kapur tohor $5 \%$ (5 gram/100 ml aquades).

2) Arang dan Pasir

\section{Tahapan Penelitian}

\section{a. Tahap Persiapan}

1) Melaksanakan survey ke lokasi penelitian.

Survey ini dimaksudkan untuk pengambilan sampel awal sekaligus melakukan pengukuran kandungan Khrom yang ada di dalam limbah.

2) Menyiapkan semua alat dan bahan yang digunakan untuk proses daur ulang maupun untuk pemeriksaan

laboratorium

\section{Tahap Pembuatan Alat dan} Bahan

a. Alat proses daur ulang dibuat dari fiber glass berdiameter $50 \mathrm{~cm}$ \& tinggi $80 \mathrm{~cm}$.

b. Bahan larutan kapur tohor 5 $\%$ (5 gram/100 ml aquades)

c. Pipa pralon dengan diameter $1 / 4$ inci.

d. Empat (4) buah stoper dengan diameter $=1 / 4$ inci.

\section{Tahap Pengoperasian Alat}

Proses penelitian dapat dilaksanakan bila alat telah siap untuk digunakan. Adapun tahap penelitiannya adalah sebagai berikut :

a. Masukkan limbah Khrom Industri penyamakan kulit ke dalam alat proses daur ulang dan biarkan sampai air limbah mencapai ketinggian $10 \mathrm{~cm}$ dari permukaan alat. Kemudian ambil dengan botol sampel untuk pemeriksaan kandungan Khrom sebelum proses daur ulang di jalankan. Botol sampel tersebut diberi label.

b. Larutkan larutan Kapur tohor dengan dosis 2,0 ml ke dalam alat proses daur ulang

c. Proses dilakukan selama 5 menit.

d. Dibuka kran di alat proses daur ulang dengan debit aliran $100 \mathrm{ml} / \mathrm{menit}$.

e. Diulangi cara nomor a sampai d untuk dosis Kapur tohor 4,0 ml; 6,0 ml; 8,0 ml; $10 \mathrm{ml} ; 12 \mathrm{ml}$, waktu proses 10 menit; 15 menit; 20 menit; 25 menit; 30 menit.

f.Diulangi cara di atas dengan tiga kali pengulangan.

g. Ambil air olahan sebanyak $500 \mathrm{ml}$ untuk dianalisis ke laboratorium.

\section{Analisis Data}

Untuk menganalisa data digunakan analysis of variance, dengan model rancangan 
randomized completely block randomized design (CRD). Prosedur menghitung analisa variasi ini adalah sebagai berikut:

a. Merumuskan Hipotesa

$$
\begin{aligned}
& \mathrm{H}_{\mathrm{o}}: \mathrm{u}_{1}=\mathrm{u}_{2}=\ldots \mathrm{u}_{\mathrm{t}} \\
& \mathrm{H}_{\mathrm{A}}: \mathrm{u}_{1} \# \mathrm{u}_{2} \# \ldots \mathrm{u}
\end{aligned}
$$

b. Menentukan jumlah replikasi (blok) dan jumlah perlakuan

$$
\begin{aligned}
& \mathrm{r}=\text { jumlah blok } \\
& \mathrm{t}=\text { jumlah perlakuan } \\
& \mathrm{n}=\text { total pengamatan }
\end{aligned}
$$

c. Menghitung $\mathrm{SS}_{\mathrm{T}}, \mathrm{SS}_{\mathrm{B}}, \mathrm{SS}_{\mathrm{P}}$, $\mathrm{SS}_{\mathrm{E}}, \mathrm{MS}_{\mathrm{B}}, \mathrm{MS}_{\mathrm{P}}, \mathrm{MS}_{\mathrm{E}}$

d. Membuat tabel ANAVA

e. Mencari harga F pada tabel, design (RCBD) dan completely antar perlakuan dan $\mathrm{F}$ antar blok, pada level signifikan a dengan degree of freedom $\mathrm{f}_{1}$ dan $\mathrm{f}_{2} . \mathrm{f}_{1}$ adalah degree offreedom dari mean square yang terbesar dan $\mathrm{f}_{2}$ adalah degree of freedom dari mean square yang terkecil dari $\mathrm{MS}_{\mathrm{P}}$ dengan $\mathrm{MS}_{\mathrm{E}}$ dan $\mathrm{MS}_{\mathrm{B}}$ dengan $\mathrm{MS}_{\mathrm{E}}$

f.Menentukan daerah penolakan hipotesa

g. Tolak $\mathrm{H}_{\mathrm{o}}$, terima $\mathrm{H}_{\mathrm{A}}$ jika $\mathrm{F}$ perlakuan $>F_{a} ; d f=f_{1}, f$

h. Terima $\mathrm{H}_{\mathrm{o}}$, tolak $\mathrm{H}_{\mathrm{A}}$ jika $\mathrm{F}$ perlakuan $<\mathrm{F}_{\mathrm{a}} ; \mathrm{df}=\mathrm{f}_{1}, \mathrm{f}_{2}$

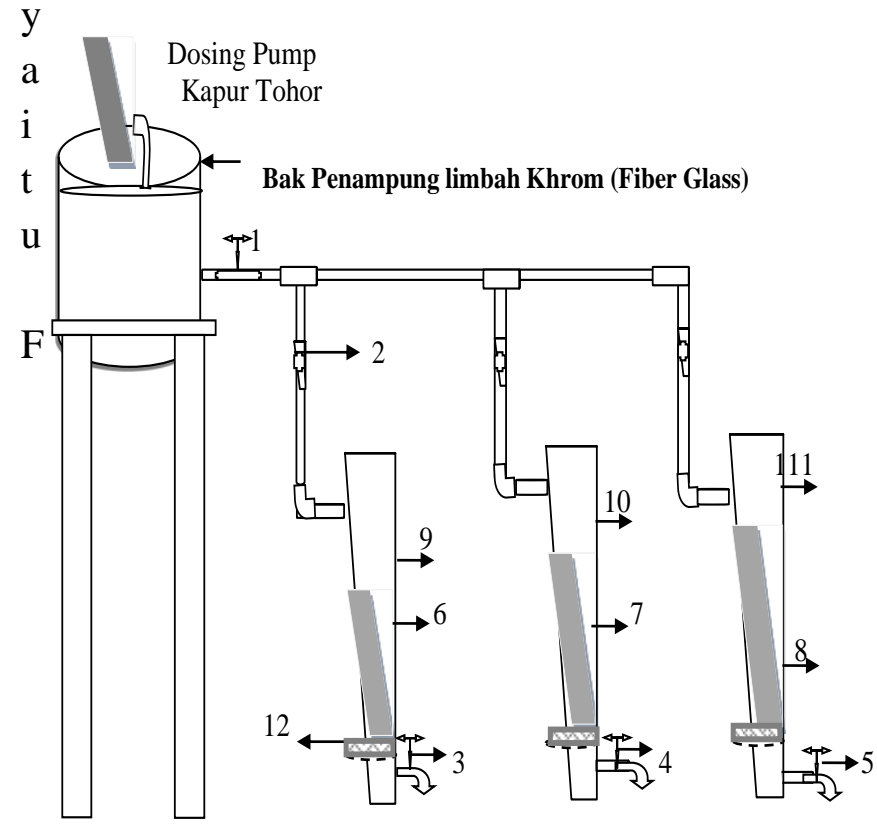

Gambar 1.Alat Daur Ulang Limbah Khrom

Keterangan gambar :
1. Kran $1 / 2 \operatorname{dim}$
5. $\quad$ Kran out let $1 / 2 \mathrm{dim}$
2. Stop Kran $1 / 2$ dim
6, 7, 8. Endapan Khrom
3. Kran out let $1 / 2 \mathrm{dim}$
9, 10, 11. Alat Daur ulang (Fiber Glass) 


\section{Kran out let $1 / 2 \operatorname{dim}$}

\section{HASIL DAN PEMBAHASAN}

\section{HASIL}

Dalam penelitian ini telah dilakukan pengambilan krom dari limbah penyamakan kulit.dengan koagulan Kapur Tohor. Pada prinsipnya proses yang terjadi adalah proses koagulasi, yaitu menggumpalkan partikel-partikel koloid dan zat-zat organik yang tersuspensi. Tahapan proses ini yaitu destabilisasi sistem koloid, pembentukan mikroflok dan aglomerasi. Partikel koloid biasanya bermuatan akibat terjadinya lapisan rangkap pada antar muka (Bahri dan Raimon 1995), dari proses tersebut diperoleh kandungan krom yang beragam. Keefektifan proses koagulasi dengan menggunakan Kapur Tohor dipengaruhi oleh $\mathrm{pH}$ larutan dan kekuatan ion dari koagulan.

\section{PEMBAHASAN}

a. Pengaruh pH

Proses koagulasi merupakan proses adsorpsi oleh koagulan terhadap partikel-partikel koloid sehingga menyebabkan destabilisasi partikel. Proses ini biasa disebut juga proses netralisasi partikel. Koagulan yang mengandung muatan berlawanan dengan muatan partikel koloid akan mengadsorpsi koloid tersebut pada permukaannya dan menurunkan gaya tolak menolak antara koloid sehingga partikel tidak terhalang lagi untuk terkoagulasi, membentuk partikel yang lebih besar dan dapat mengendap [2]. Studi penurunan kadar kromium (III) dengan Kapur Tohor sebagai koagulan dimulai dengan mengamati variasi $\mathrm{pH}$ agar dapat diketahui $\mathrm{pH}$ optimum koagulasi. Variasi $\mathrm{pH}$ yang dilakukan dalam penelitian ini adalah pH 4; 5; 6; 7; 8;9;10;11; 12 dan 13.

Larutan kerja yang digunakan sebagai limbah cair penyamakan kulit merupakan larutan kromium total (Cr) dengan kandungan krom1,6 mg/L diatur $\mathrm{pH}$ awalnya dengan penambahan $\mathrm{NaOH}$. Setelah itu masing-masing larutan yang telah diatur $\mathrm{pH}$ nya ditambah larutan Kapur Tohor(2,0; 4,0; 6,0; $8,0 ; 10 ; 12) \mathrm{mg} / \mathrm{L}$ yang berfungsi sebagai koagulan. Selanjutnya masing-masing larutan diaduk menggunakan magnetic stirrer dengan kecepatan $600 \mathrm{rpm}$, proses pengadukan cepat ini bertujuan untuk membentuk inti flok, kemudian dilanjutkan pengadukan lambat dengan kecepatan $300 \mathrm{rpm}$, proses pengadukan lambat akan memperpendek jarak antar partikel sehingga gaya tarik-menarik antar partikel menjadi lebih besar dan dominan dibandingkan gaya tolaknya.

Setelah proses pengadukan selesai larutan didiamkan sampai terjadi pengendapan yang 
sempurna. Setelah proses pengendapan selesai, dilakukan proses penyaringan agar terjadi pemisahan antara filtrat dan endapan. Filtrat yang diperoleh merupakan kadar $\mathrm{Cr}$ yang tidak terkoagulasikan kemudian dianalisis dengan SSA pada $\lambda 357,9 \mathrm{~nm}$. Tabel 5.1 dan Gambar 5.1 dan 5.2 ditampilkan hubungan $\mathrm{pH}$ dengan prosen penurunan kromium yang terdapat dalam filtrate.

Tabel 1. Prosentase Penurunan Kromium dengan Variasi $\mathrm{pH}$ Limbah Penyamakan Kulit

\begin{tabular}{|c|c|c|}
\hline $\mathbf{0}$ & $\mathbf{p H}$ & \% Penurunan $\mathbf{C r}$ \\
\hline & 4 & 51,5638 \\
\hline & 5 & 57,7340 \\
\hline & 6 & 71,5563 \\
\hline & 7 & 99,5553 \\
\hline & 8 & 99,6881 \\
\hline & 9 & 99,8848 \\
\hline & 10 & 99,9889 \\
\hline & 11 & 99,9620 \\
\hline
\end{tabular}

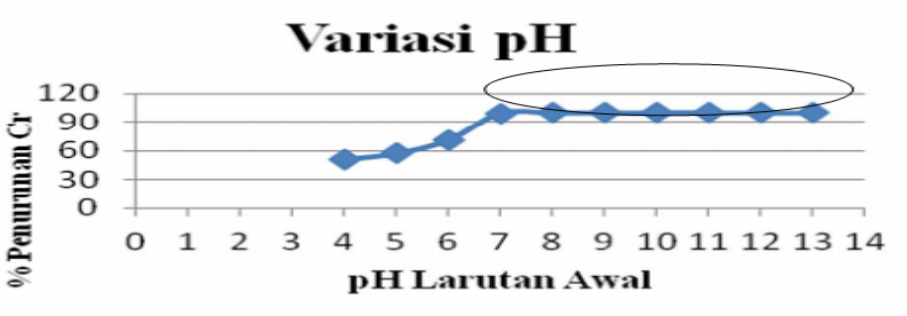

Gambar 2. Grafik Pengaruh Variasi pH terhadap \% Penurunan $\mathrm{Cr}$

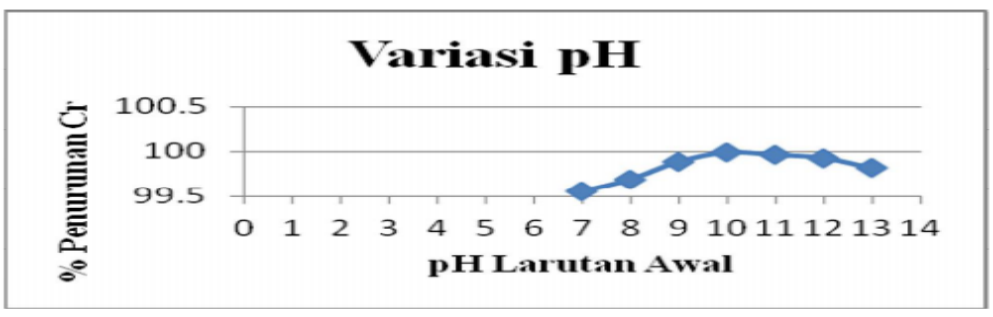

Gambar 3.Perbesaran grafik pada kisaran pH 7-13

Dari Gambar 2 terlihat karena pada $\mathrm{pH}$ tersebut ion bahwa prosen penurunan terkecil OHyang terkandung pada larutan terjadi pada $\mathrm{pH} \mathrm{4}$, hal ini terjadi tidak cukup banyak sehingga tidak 
banyak $\mathrm{Cr}$ yang terendapkan pada kondisi $\mathrm{pH}$ tersebut. Dari Gambar2 juga dapat dilihat bahwa prosen penurunan terbesar terjadi pada pH 10 dengan prosen penurunannya mencapai 99,9889\%. Menurut Benefield $\mathrm{Cr}(\mathrm{OH}) 3$ adalah senyawa yang bersifat amfoter dan akan melarut minimum pada $\mathrm{pH}$ antara 7,5-10.

\section{b. Pengaruh Variasi Konsentrasi Koagulan}

Setelah didapatkan $\mathrm{pH}$ optimum dari percobaan sebelumnya, maka dilakukan percobaan variasi konsentrasi koagulan. Variasi Konsenttrasi koagulan ini dilakukan dengan tujuan untuk mengetahui bagaimana pengaruh konsentrasi koagulan terhadap penurunan jumlah kromium. Variasi konsentrasi koagulan Kapur Tohor yang dipakai dalam percobaan ini adalah $(2,0 ; 4,0$; $6,0 ; 8,0 ; 10 ; 12) \mathrm{mg} / \mathrm{L}$. Larutan kerja yang merupakan larutan kromium dengan konsentrasi 3,6 $\mathrm{mg} / \mathrm{L}$ diatur $\mathrm{pH}$ nya dengan penambahan $\mathrm{NaOH}$ sampai $\mathrm{pH} 10$.

Kemudian masing-masing larutan kerja yang telah diatur $\mathrm{pH}$ nya ditambahkan koagulan dengan variasi konsentrasi yang telah disebutkan sebelumnya dan dilakukan koagulasi. Hasil pengukuran kadar $\mathrm{Cr}$ yang ada dalam filtrat di berikan pada Tabel 2 .

Tabel 2. Prosentase Penurunan Kromium dengan Variasi konsentrasi

Kapur Tohor

\begin{tabular}{|cc|}
\hline Konsentrasi Kapur Tohor $(\mathrm{mg} / \mathrm{L})$ & \%PenurunanCr \\
\hline 2 & 99,80 \\
\hline 4 & 99,88 \\
\hline 6 & 99,96 \\
\hline 8 & 99,98 \\
\hline 10 & 99,98 \\
\hline 12 & 99,96 \\
\hline
\end{tabular}

Senyawa koagulan adalah senyawa yang mempunyai kemampuan mendistibilasi koloid dengan cara menetralkan muatan listrik pada permukaan koloid sehingga koloid dapat bergabung satu sama lain membentuk flok yang berukuran lebih besar sehingga mudah mengendap . Koagulan digunakan untuk membantu dalam proses koagulasi dan flokulasi dengan mempercepat proses flokulasi atau memperkuat flok untuk membuatnya lebih mudah untuk mengendap. Analisa proses diutamakan untuk mengetahui pengaruh dosis koagulan terhadap penurunan kadar kromium dalam limbah sintetis. 
Koagulan akan menjadi inti dari flok yang terbentuk dan akan meningkatkan densitas flok, dan mempercepat proses sedimentasi. Setelah penambahan dosis koagulan $200 \mathrm{mg} / \mathrm{L}$ terlihat bahwa nilai efisiensi penurunan kromium mulai menurun hal ini disebabkan partikel efluen dikelililingi banyak partikrel koagulan yang ditambahkan, ketika partikel koagulan berada dalam jumlah besar maka dapat dikatakan permukaan patikel efluen berada dalam keadaan kondisi jenuh sehingga kemungkinan keduanya untuk bereaksi sangat kecil.

Pengaruh Waktu kontak setelah didapatkan $\mathrm{pH}$ dan dosis koagulan optimum dari percobaan sebelumnya, proses penurunan kadar kromiium dalam penelitian ini juga dilakukan menggunakan variasi waktu kontak pengadukan dalam proses koagulasi. Varasi waktu pengdukan lambat yang digunakan adalah $10 ; 30 ; 45$; dan 120 menit. Setelah proses pengadukan selesai larutan didiamkan sampai terjadi proses pengendapan yang sempurna. Setelah itu larutan disaring dengan kertas saring whatman ukuran 42. Kemudian filtrat yang dikumpulkan diuji kadar kromiumnya dengan menggunakan SSA pada $\lambda 357,9 \mathrm{~nm}$. Data hasil pengukuran yang diberikan pada Tabel 3 dan Gambar 4 di bawah ini.

Tabel 3. Prosentase Penurunan Kromium dengan Variasi Waktu Pengadukan

\begin{tabular}{|cr|}
\hline Waktu (menit) & \%Penurunan $\mathrm{Cr}$ \\
\hline 10 & 99,9685 \\
\hline 30 & 99,9747 \\
\hline 45 & 99,9743 \\
\hline 120 & 99,9725 \\
\hline
\end{tabular}

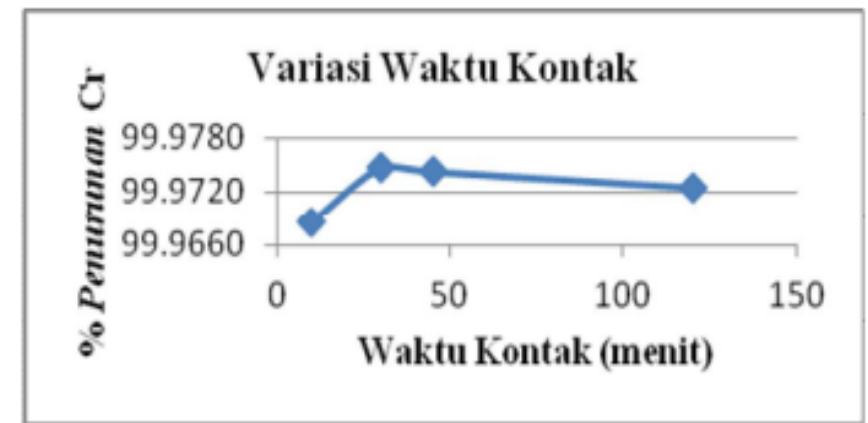

Gambar 4. Grafik Variasi Waktu Kontak terhadap $\%$ Penurunan $\mathrm{Cr}$ 
Gambar 4 menunjukkan bahwa waktu kontak optimum untuk menurunkan kadar kromium dari proses koagulasi adalah 30 menit dengan nilai efisiensi penurunan kroimium adalah 99,9747 \%. Pengadukan lambat diperlukan untuk proses memperpendek jarak antar partikel sehingga gaya tarik-menarik antar partikel menjadi lebih besar dan dominan dibandingkan gaya tolaknya, sehingga menghasilkan kontak dan tumbukan antar partikel yang lebih banyak dan lebih sering.
Kontak inilah yang menggumpalkan partikel-partikel padat terlarut terkoagulasi berukuran mikro menjadi partikel-partikel flok yang lebih besar. Flok-flok ini kemudian akan beragregasi. Ketika pertumbuhan flok sudah cukup maksimal (massa, ukuran), flok-flok ini akan mengendap ke dasar wadah, sehingga terbentuk dua lapisan yaitu lapisan jernih yang berada pada bagian atas dan endapan pada bagian bawah.

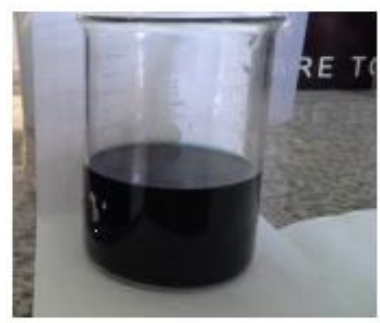

Gambar 5. Sampel Limbah Cair Penyamakan Kulit

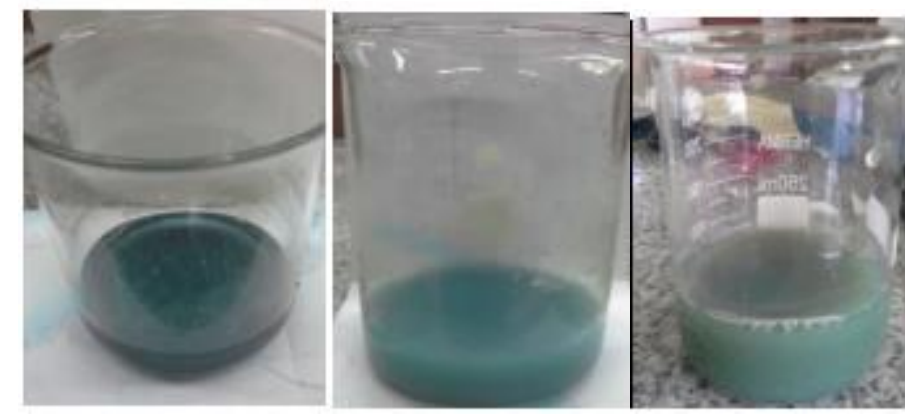

(a)

(b)

(c)

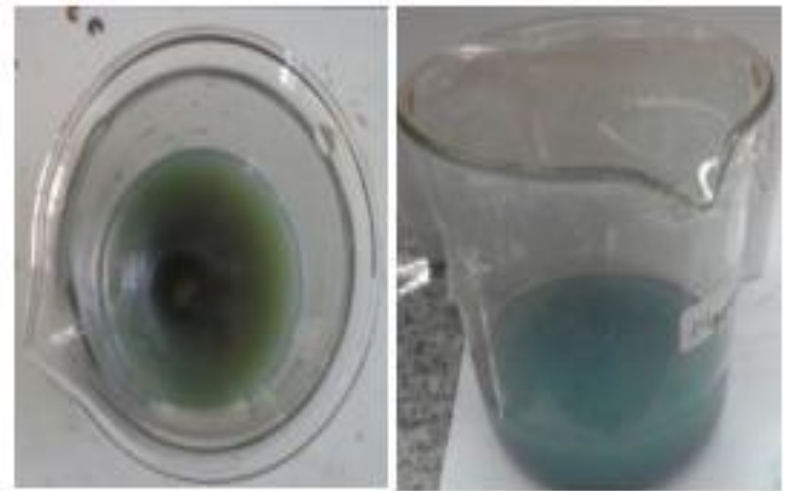


Gambar 6. (a) Sampel limbah cair penyamakan kulit; (b) setelah penambahan $\mathrm{NaOH}$; (c) setelah penambahan FeSO4; (d) saat proses pengadukan; (e) setelah proses pengadukan.

\section{E. KESIMPULAN DAN SARAN}

\section{Kesimpulan}

Dari penelitian yang telah dilakukan dapat disimpulkan bahwa proses pemisahan kromium dengan koagulan Kapur Tohor optimal pada $\mathrm{pH}$ 10, dosis koagulan sebesar $200 \mathrm{mg} / \mathrm{L}$ dan waktu optimal untuk pengadukan lambat pada 30 menit. Dalam limbah cair penyamakan kulit prosentase pemisahan kromium yang dapat terjadi pada keadaan optimal adalah sebesar $99,9850 \%$.

\section{Saran}

Meskipun koagulan Kapur tohor merupakan teknologi pengolahan limbah B3 yang bersifat final, karena diversifikasi energi oleh industri menjadi pertimbangan penting maka perlu diteliti kemungkinan pemakaian bahan koagulan lain, sehingga pada aplikasi pemanfaatan limbah lumpur krom pada industri penyamakan kulit dapat mengurangi pemakaian bahan limbah B.

\section{F. DAFTAR PUSTAKA}

Bahri, S. dan Raimon, 1995. Efisiensi Penurunan COD Air Limbah Tekstil dengan Proses
Koagulasi dan Flokulasi, Laporan Penelitian

Departemen Perindustrian (BIPA), Palembang

Benefield LD, Borro LW, Joseph., 1990. Proces Chemistry for Water and Wastewater Treatment, New Jersey. Prentice Hall .

Kusumawati, T., 2006.Jerapan Kromium Limbah Penyamakan Kulit oleh Zeolit Cikembar dengan Metode Lapik Tetap. Skripsi Departemen Kimia, Institut Pertanian Bogor. Bogor.

K.M.N. Islam., Ahmed Kamruzzaman Khaled Misbahuzzuman., Majumader., Milan Chkrabarty. 2011. Efficiency of diffrent Combination for Thretment of Tannery Effluents: a case study of Bangladesh. African Journal Environmental and Science and Technology 409-419

Wardhani, E., Dirgawati M., Valyana K.P., 2012.Penerapan Metode Elektrokoagulasi dalam Pengolahan Air Limbah Industri Penyamakan Kulit. Jurusan Teknik Lingkungan, Itenas. Bandung.

Wahyuningtyas, N., 2001. Pengolahan Limbah Cair Khromium dari Proses Penyamakan Kulit Menggunakan Senyawa Alkali Natrium Karbonat (Na2CO3).STTL. Yogyakarta 
Lofrano, G., Meriç, S., Zengin, G. E., \& Orhon, D. (2013). Chemical and biological treatment technologies for leather tannery chemicals and wastewaters: A review. Science of The Total Environment, 461462 , 265-281. https://doi.org/10.1016/j.scitote nv.2013.05.004

Pan, H., Li, G.-L., Liu, R.-Q., Wang, S.-X., \& Wang, X.-D. (2017). Preparation, characterization and application of dispersible and spherical Nano-SiO 2 @ Copolymer nanocomposite in leather tanning. Applied Surface Science, 426, 376-385. https://doi.org/10.1016/j.apsusc. 2017.07.106 